\title{
DEPARTMENT STORE LIABILITY IN RUSH SALES
}

\section{STACY WEAVER, JR.*}

$X$ Department Store advertises a bargain sale with sizable reductions in all of its prices. Plaintiff-housewife attends at the advertised hour to find that a large crowd has assembled at the entrance due to the delayed opening of the doors. The size of the crowd and its impatience increase. Plaintiff-housewife is pressed against the plate glass display windows which break under pressure and the plaintiff is injured. Plaintiff-housewife sues X Department Store.

Though the occurrence of the above situation may not be infrequent, appeals prosecuted to an appellate court are scanty. Interesting questions are presented which have not been determined with any satisfactory degree of finality by the cases. Was X Department Store negligent, i.e. would a reasonable man in the shoes of $X$ Department Store have foreseen risk to this plaintiff? If so, at what point in the chain of events was the duty of reasonable care on the part of the defendant violated? Should the defendant have reasonably anticipated the action of the crowd or was such action an independent and intervening cause breaking the chain of causation? Did the plaintiff assume the risk? What instructions are to be given the jury?

Reasonably diligent search reveals four cases directly in point, one of which is quite recent, ${ }^{1}$ which are confiicting as to result and method. What may be said to be the leading case from the standpoint that it was one of the earliest decided and is most frequently cited is that of Greeley $v$. Miller's Inc. ${ }^{2}$ In this case the facts substantially parallel those in the hypothetical case with the exception that the defendant department store had employed two supernumerary policemen to prevent too many customers from entering at one time. The plaintiff waited approximately thirty minutes for the store's opening beyond the advertised opening time. As the crowd surged forward, the pressure

* 2d year law student, Duke University; A.B. Duke 1951.

240 S.W.2d 373 (Tex.Civ.App. 1951).

$=111$ Conn. 501, 150 Atl. 500 (1930). 
against the display windows caused them to break and the falling glass injured the plaintiff. The plaintiff made a threefold claim of negligence on the part of the defendant department store: (1) that the defendant knew or should have known that the advertisement would draw a large number of people to the store and that so large a number in the entrance, in close proximity to the plate glass windows, might break them unless there were barriers of protection; (2) that the failure to open the doors at the specified hour caused the crowd to be restless thereby increasing the danger; (3) that the defendant saw or should have seen the crowd pressing, but despite this failed to open the doors or to take any other measures to protect the prospective customers from the danger of the breaking windows. In the lower court a verdict was directed for the defendant. The appellate court reversed saying that the jury might reasonably have found these additional facts: that the defendant should have known that the late opening of the store would increase the number of people waiting; that it in fact knew or should have known that those in the entranceway "could not well withstand the pressure of the throng behind them or govern the direction in which they went"; 3 that it knew or should have known that the windows would break if subjected to severe pressure.

\begin{abstract}
"Although the defendant knew or should have known this condition, it failed to make any effort to control the crowd or to open its doors and thus avoid or lessen the danger liable to arise out of this condition. The control of this situation was in its own hands, and it failed entirely to exercise it in a reasonable way."
\end{abstract}

The court seems to say here that the defendant should have not only anticipated the crowd but also the risk of its actions towards this class of plaintiffs. It held that if there were no contributory negligence, the jury could have found the negligence of the defendant to be the proximate cause of the injury to the plaintiff. The court further indicated that

\footnotetext{
3 Supra, note 2 at 501.

- Supra at note 3 .
} 
the facts in evidence did not justify a conclusion of negligence from the failure to barricade the windows.

An identical case, solely from the standpoint of the factual situation, arose in Texas three years later in Rincon v. Berg $\mathrm{Co}^{5}$ There the plaintiff was injured under similar circumstances and made several allegations of the defendant's negligence. The case was submitted to the jury on twelve special issues only one of which was relevant to the defendant's negligence.

"Do you find from a preponderance of the evidence it was negligent on the part of the said Berg Company to fail to have said windows boarded up or take other precautions for the safety of parties seeking to attend the sale then in progress?"B

The effect of the jury's verdict was that the accident was not unavoidable and that the failure to board the windows or take other precautions was negligence on the part of the defendant. The trial judge rendered judgment n. o. v. for the defendant. As only one issue was submitted, the appellate court did not discuss the defendant's contention of assumption of risk and contributory negligence of the plaintiff, as such, but confined its discussion to proximate cause. Making reference to an evidently long-standing and revered definition of proximate cause by an earlier Texas court, the court continued,

"A party should not be held responsible for the consequences of an act which ought not reasonably to have been foreseen? In other words, it ought not be deemed negligence to do or to fail to do an act when it was not anticipated, and should not have been anticipated, that it would result in injury to anyone." 7

Applying this to the case under consideration, the court asked,

"Can it be said that the Berg Company could have reasonably foreseen that, if it failed to board up

\footnotetext{
- 60 S.W.2d 811 (Tex.Civ.App. 1933).

- Supra, note 5 at 813 .

Tupra, note 5 at 814 .
} 
its display windows, a crowd would come to attend the sale, the members of which would become so impatient that they would push other members against the display windows in the entrance, thereby injuring them? We think not."8

The court distinguished the Greeley case on two grounds: (1) that there was in that case a pleading of a failure to open the doors in time and that the defendant failed to open the doors after it saw the crowd pressing against the windows (which was not alleged in the Rincon case); and (2) that the court held there that the facts would not support a conclusion of the defendant's negligence on the failure to barricade alone. On that basis (as the failure to barricade was the only issue submitted), the Rincon case does not appear to be inconsistent with the Greeley case.

Still three years later in the District of Columbia came the case of Schwartman v. Lloyd. ${ }^{9}$ There the plaintiff arrived one half hour after the sale had started. A crowd had gathered outside the defendant department store and customers were being allowed to enter seven or eight at a time by the defendant's agents. Each time there was a surge, one of which cracked the display windows and pitched the plaintiff folward on the ground cutting her legs. The resulting disturbance caused premature birth of a child, attempts at suicide, and confinement in a hospital and her home. The plaintiff alleged that the defendant was negligent and that such negligence was the proximate cause of the plaintiff's injury in that: (1) the defendant failed to protect the windows when the defendant or its agents saw, or by the exercise of reasonable care could have seen the crowd pressing against the display windows; (2) that the defendant failed to prevent the breaking of the windows after it saw or by the exercise of reasonable care should have seen the windows breaking. There was no affirmative plea of defense and the defendant's motion for a directed verdict was denied. The reviewing court held for the plaintiff who relied a great deal on the Greeley case. The defendant pointed out

- Supra at note 7.

- 82 F.2d 822 (D.C.Clr. 1936). 
that the court there had rejected a conclusion of the defendant's negligence on the issue of barricading the windows. Said the court,

"But we think this statement, taken in connection with the whole of the case, meant only that the failure to place barriers would not alone have justified a conclusion of negligence if other reasonable means to prevent injury had been used by the defendant." 10

The ground of the court's decision was not that it was negligence on the part of the department store to attract a crowd to its store and it accordingly purported to lay down no rule prohibiting these sales, but it based its decision on the manner in which the attracted crowd was held and handled. It held that evidence showing that the fiow of the crowd is dammed without warnings, barricades, or guards was sufficient to enable a reasonable jury to find the defendant negligent. ${ }^{11}$

The most recent decision involving this situation was also decided in Texas: Fair Stores v. Lane. ${ }^{12}$ The plaintiff broke her leg under circumstances identical with the previous cases. She alleged the defendant was negligent in eight specific instances to which the defendant answered that the injury was due to the action of third persons, the plaintiff's negligence, and that the accident was unavoidable. .Upon submission of the case to the jury, the defendant was found to have committed four acts of negligence which were the proximate cause of the plaintiff's injury: (1) failure of the defendant's agents to properly police the premises; (2) failure to open doors at the advertised time; (3) failure to rope off the entrance; (4) and failure to have its agents police and keep the crowd from pushing. Judgment was rendered for the plaintiff. The appellate court reversed utilizing the medium of proximate cause. The court purported to follow the Rincon case indicating that the action of the crowd was a new and independent cause of the plaintiff's injuries. It

\footnotetext{
10 Supra, note 9 at 825 .

u Supra, note 9 at 827 .

12 Supra at note 1.
} 
concluded, "As far as this record is concerned, Mrs. Lane's injuries are not the natural and probable result of the appellant's negligent act or omission."13 Again a court was called on to consider the Greeley case. It was distinguished on the ground that there the jury found that the defendant knew or should have known that a disorderly crowd would press the plaintiff against the door, or some other object, in such a way as to break the plaintiff's leg whereas there was no such finding in the case under consideration. ${ }^{14}$

Section 281 of the Restatement of the Law of Torts states the elements of a cause of action for negligence:

"The actor is liable for an invasion of an interest of another, if:

(a) the interest invaded is protected against unintentional invasion, and

(b) the conduct of the actor is negligent with respect to such interest or any other similar interest of the other which is protected against unintentional invasion, and

(c) the actor's conduct is a legal cause of the invasion, and

(d) the other has not so conducted himself as to disable himself from bringing an action for such invasion."

The attempt to resolve the cases under consideration in terms of legal or proximate causation merely serves to obscure the real issues. Under the Restatement analysis the only elements necessary to establish liability for negligence which are genuinely in doubt are whether the defendant was negligent and whether the plaintiff conducted himself, or as is more typically the case, herself, so as to be unable to maintain an action. There is no real question of legal causation because if the defendant was negligent at all his negligence consisted of creating an unreasonable risk of the particular type of injury which the plaintiff sustained..$^{15}$

\footnotetext{
13 Supra, note 1 at 377 .

. ${ }^{14} \mathrm{~A}$ dubious distinction in view of the verdict of the lower court in this case.

Is See comment $e$ to section 281 of the Restatement of Torts .
} 
When the injury which occurs is the particular hazard which makes the defendant's conduct negligent, it is clear that it must be a proximate consequence of such negligence. Otherwise a court would be confronted with the anomalous situation of holding that the defendant was negligent because he created the risk of a particular hazard, but that he was not liable when the very injury which made his conduct negligent actually eventuated.

In attempting to analyze whether the defendant has been negligent in these cases it will be helpful to consider just what the defendant did (or failed to do) which may be held to have created an unreasonable risk of injury. Typically, one of the plaintiff's allegations is that the defendant was negligent in failing to open the doors at the advertised hour with knowledge of the nature of the crowd gathered. It would seem that something less than a reasonable man seeing the crowd jamming against the display windows, would realize that by not opening the doors some one of its members might be injured. The verdicts returned in these cases sustain this contention. ${ }^{16}$ The same factors seem to underlie allegations of the defendant's negligence in failing to give some warning to the crowd or to have its agents police the premises: At least, a jury question is presented. The Lane case referred to the act of the crowd as the proximate cause of the plaintiff's injuries. The decision might better be based on the negligence issue since proximate cause in this type of case where the hazard which occurred was the particular hazard which would have made the defendant's conduct negligent is scarcely open to serious question.

However, whether failure to barricade the display windows is negligence is another matter. All these cases hold that this alone is insufficient evidence of a similarly situated defendant's negligence. Such a conclusion appears sound since risk to the plaintiff could be eliminated by proper policing or less onerous means. Though a reasonable man

10 At this point the magnitude of the risk created must be weighed against the social utility of the conduct of the defendant. It seems reasonable to conclude that bargain sales in department stores are not socially desirable to the extent that their privilege is complete. 
might foresee injury to someone in the crowd after it has gathered and its conduct is such that a reasonable man would take some affirmative steps to assure the safety of its members, the courts have been unwilling to require the defendant to barricade. ${ }^{17}$ The court in the Rincon case, purporting to base its decision solely on the issue of barricading, might have held as a matter of law that this was not negligence and avoided the confusion of the new and independent cause argument.

The plaintiff-housewife, then, would appear to make out a case of actionable negligence providing she has not disabled herself within the meaning of (d) under section 281 of the Restatement of Torts. The most probable bar to the plaintiff's recovery would seem to be the doctrine of assumption of risk, ${ }^{18}$ however, contributory negligence has also been utilized by the defendant in these cases. ${ }^{10}$ The former is based on the consent of the plaintiff and the only possible basis for a reasonable contention that the plaintiff in these cases gave her consent to relieve the defendant of liability would be by implication from her conduct. Schwartzman $v$. Lloyd held that "the public assumes the ordinary risks of ordinary crowds."20 Generally, however, there must be full knowledge and appreciation of the risk and a voluntary encountering of it by the plaintiff. ${ }^{21}$ This was not true in these cases.

Much of the confusion in these cases seems to have resulted from a failure of the plaintiff attorneys to specifically indicate the defendant's negligence. The cases have made a differentiation. To allege that the defendant was negligent in failing to open its doors at the advertised hour, in failing to warn and have its agents police the premises

\footnotetext{
17 Imagine the absurdity of requiring the store to secure boards and a hammer when opening the door would alleviate the situation in a simple manner.

18 The facts of these cases suggest this doctrine as a more plausible defense than that of contributory negligence.

10 Contributory negligence of the plaintiff was an affirmative plea of defense in Rincon $v$. Berg Co. and Fair Stores $v$. Lane. As assumption of risk is a facet of negligence, contributory negligence will be assumed to bave the same effect as assumption of risk.

so supra at note 11.
} 
without pointing out exactly when these failures were unreasonable is to invite a court to utilize the independent and intervening cause argument. A defendant department store should not be held to account for its failure to anticipate this injury until a large restless crowd has gathered. At that point it is not an unrealistic standard of care to require such a defendant to take some affirmative steps to prevent unnecessary threat of harm to a plaintiff so situated. Pleadings and proof in accordance with this make it difficult for a reviewing court to manipulate proximate cause in such a manner as to release the defandant from liability, for the nature and the actions of the crowd are part of the surrounding circumstances that the defendant, as a reasonable man, is bound to take into account. This is a fair inference from the cases adjudicated. 